\title{
PELATIHAN PEMBUATAN HANDSANITIZER ALAMI DENGAN EKSTRAK DAUN SIRIH DAN JERUK NIPIS UNTUK MENCEGAH PENYEBARAN COVID-19 DI DESA CUPAT PARITTIGA
}

\author{
Feri Ardiansah ${ }^{1}$, Silawati $^{2}$, Yesi $^{3}$, Yuhani $^{4}$, Fatayah Nur Isnani $^{5}$ \\ 1,2,3,4,5 Fakultas Keguruan dan Ilmu Pendidikan Universitas Muhammadiyah Bangka Belitung \\ e-mail: feri.ardiansah@stkipmbb.ac.id ${ }^{1}$, silasupandi@gmail.com ${ }^{2}$, yesstkip@gmail.com³ \\ yuhaniyhuyu11@gmail.com ${ }^{4}$, fatayahnur9@gmail.com ${ }^{5}$
}

\begin{abstract}
Abstrak
Beberapa cara untuk mencegah penyebaran covid-19 yaitu dengan menerapkan $3 \mathrm{M}$ (mencuci tangan, menjaga jarak, dan menggunakan masker). Semakin bertambahnya kesibukan masyarakat dan menginginkan cara yang praktis dan efisen waktu dalam mencuci tangan, sehingga memunculkan inovasi untuk membuat cairan antiseptik berupa handsanitizer alami. Zat antiseptik yang terdapat didalam handsanitizer memiliki presentase alkohol 60-95\%. Terdapat penelitian mengungkapkan bahwa daun sirih dengan kandungan ekstrak lebih dari 15\% setara dengan kandungan alkohol dan etanol. Daun sirih mengandung berbagai macam kandungan seperti tanin, polifenol serta steroid. Sedangkan jeruk nipis memiliki kandungan kalsium, fosfor, zat besi, vitamin A, vitamin B1, karbohidrat, kalsium, energi dan vitamin C. Kedua bahan ini mengandung zat anti bakteri. Di desa Cupat tidak semua warga membudidayakan tanaman sirih dan jeruk nipis yang dapat digunakan untuk membuat handsanitizer alami. Handsanitizer alami ini dibuat tanpa campuran alkohol dan memanfaatkan daun sirih dan jeruk nipis yang ada di desa Cupat. Kegiatan ini adalah rangkuman dari inovasi dan bentuk pelatihan untuk mengajak masyarakat di desa Cupat memahami cara membuat handsanitizer alami ekstrak daun sirih merah dan jeruk nipis.
\end{abstract}

Kata Kunci: COVID-19, Handsanitizer, Ekstrak Daun Sirih, Jeruk Nipis, Desa Cupat

\begin{abstract}
Several ways to prevent the spread of covid-19 are by applying $3 M$ (washing hands, maintaining distance, and using masks). Increasingly busy people and wanting a practical and time-efficient way to wash their hands, has led to an innovation to make an antiseptic liquid in the form of a natural handsanitizer. The antiseptic substances contained in the handsanitizer have an alcohol percentage of $60-95 \%$. There are studies that reveal that betel leaf with an extract content of more than $15 \%$ is equivalent to alcohol and ethanol content. Betel leaf contains various kinds of ingredients such as tannins, polyphenols and steroids. While lime contains calcium, phosphorus, iron, vitamin A, vitamin $B 1$, carbohydrates, calcium, energy and vitamin $C$. Both of these ingredients contain anti-bacterial substances. In Cupat village, not all residents cultivate betel and lime plants which can be used to make natural handsanitizers. This natural handsanitizer is made without a mixture of alcohol and utilizes betel and lime leaves in Cupat village. This activity is a summary of innovation and forms of training to invite the community in Cupat to understand how to make natural handsanitizers for red betel leaf extract and lime.
\end{abstract}

Keywords: COVID-19, Handsanitizer, Betel Leaf Extract, Lime, Cupat Village 


\section{PENDAHULUAN}

Virus corona adalah virus RNA yang memiliki ukuran partikel $120 \mathrm{~nm}-160 \mathrm{~nm}$. Virus ini menginfeksi hewan diantaranya kelelawar dan unta. Corona virus yang menjadi etiologi covid-19 termasuk dalam genus betacoronavirus. Penyebaran atau transmisi SARS-CoV-2 dari manusia ke manusia menjadi sumber utama sehingga penyebarannya menjadi lebih agresif (Susilo dkk $2020: 46$ ).

Ditengah adanya pandemi covid-19 yang sekarang ini menimpa dunia, saat ini setiap kebutuhan atau perilaku pola hidup bersih dan sehat meningkat. Kesadaran akan mencuci tangan untuk menjaga kesehatan diterapkan di indonesia semenjak covid-19 masuk ke indonesia ( Thalib, 2020: 31). Cuci tangan menggunakan sabun dan air merupakan cara paling efektif dalam membersihkan kotoran pada perkumpulan kulit, dari berbagai mikroorganisme serta virus, namun terkadang mencuci tangan menjadi hal yang merepotkan karena tidak semua sudut ruangan terdapat air dan sabun. Antiseptik merupakan bahan kimia mikroorganisme pada permukaan tubuh dengan cara membunuh mikroorganisme tersebut atau menghambat pertumbuhan dan aktivitas metaboliknya.

Seiring dengan bertambahnya kesibukan masyarakat memicu munculnya inovasi produk pembersih tangan instan yang dapat dipakai dimanapun tanpa air yang handsanitizer merupakan zat antiseptik dengan persentase alkohol sebesar 60-90\% terdapat pada handsanitizer memiliki kemampuan aktivitas bakteorisida yang baik terhadap bakteri gram positif dan negatif untuk menghilangkan kuman kurang dari 30 detik. Tanaman yang dapat dimanfaatkan sebagai tanaman obat adalah daun sirih. Daun sirih dapat digunakan untuk mengobati berbagai jenis penyakit seperti obat pembersih mata, menghilangkan bau badan, mimisan, sariawan, pendarahan gusi, batuk, keputihan dan obat kulit sebagai perawatan untuk kecantikan atau kehalusan kulit.

Tanaman daun sirih ini sudah hampir langka untuk ditemui namun ada dipemukiman warga desa cupat tepatnya di RT 10. Dengam memanfaatkan daun sirih, KKN Desa Cupat berinisiatif untuk membuat handsanitizer alami ekstrak daun sirih yang mampu untuk membunuh bakteri maupun virus sehingga dapat mengurangi penyebaran covid-19 ditengah pandemi saat ini, terlebih sulit memperoleh alkohol dan mahalnya handsanitizer membuat masyarakat enggan membeli. 
Salah satu program kerja KKN Desa Cupat yaitu Pembuatan Handsanitizer alami berbahan dasar daun sirih dan jeruk nipis. Terdapat penelitian mengungkapkan bahwa air rebusan daun sirih memiliki kandungan ekstrak lebih dari $15 \%$ setara dengan kandungan alkohol dan etanol. Sedangkan jeruk nipis berfungsi untuk menetralisir warna dari rebusan air daun sirih serta sebagai campuran yang dapat memberikan ketahanan ekstrak daun sirih tersebut.

Banyak masyarakat di desa cupat belum paham jika handsanitizer alami ini mampu membersihkan bakteri dan sebagai pengganti sabun untuk mencuci tangan. Maka dari itu kelompok KKN desa cupat menyelanggarakan pelatihan cara pembuatan handsanitizer alami.

\section{METODE}

Metode yang digunakan yaitu metode ceramah dan simulasi dengan langkah-langkah berikut:

1. Siapkan alat dan bahan yang digunakan

2. Cuci daun sirih dan jeruk nipis sampai bersih

3. Potong daun sirih menjadi kecil-kecil kemudian taruh didalam wadah

4. Tambahkan $100 \mathrm{ml}$ air kedalam wadah yang telah berisi daun sirih

5. Didikan air dalam panci setelah mendidih kukus/steam daun sirih dan air.

6. Tunggu sekitaran 15 menitan dan tiriskan. Tunggu hingga dingin

7. Potong jeruk nipis kemudian peras dan saring

8. Campurkan rebusan air daun sirih dan perasan jeruk nipis

9. Masukan campuran kedalam botol

10. Handsainitizer siap digunakan

\section{HASIL DAN PEMBAHASAN}

\begin{tabular}{|l|l|}
\hline Pemeriksaan & Hasil \\
\hline Bentuk & Cair \\
Warna & Kecoklatan \\
Bau & Sirih \\
\hline
\end{tabular}

Dari hasil tabel diatas tersebut mengambarkan Organoleptis dari handsanitizer yang dibuat dengan ekstrak daun sirih sesuai dengan rancangan formula. Dari setiap bahan memiliki kandungan dan manfaat tersendiri. Daun sirih memiliki kandungan kimia antara lain saponin, 
flavonoid, poliferol, dan minyak atsiri. Senyawa saponin dapat bekerja sebagai antimikroba. Senyawa ini akan merusak sitoplasma dan membunuh sel. Senyawa flavonoid memiliki mekanisme kerja mendenaturasi protein sel bakteri dan merusak membrane sel tanpa dapat diperbaiki lagi (Caroline, dkk, 2016).

Kandungan aktif jeruk nipis antara lain kalsium, fosfor, zat besi vitamin A, vitamin B1, karbohidrat, kalsium, energi dan vitamin C. Produk handsanitaizer dari bahan alami yaitu mengguanakan berbagai bahan dari tumbuhan yang mudah didapatkan disekitar lingkungan tempat tinggal, mempunyai aroma khas dan telah terbukti dapat menbunuh kuman. Cara pembuatan handsanitaizer alami menggunakan alat-alat yang murah dan sederhana sesuai dengan kalangan ekonomi masyarakat. Pelatihan pembuatan handsanitaizer alami diperoleh hasil berupa khasiat antivirus, higenis dan aroma segar. Handsenitaizer sangat berguna untuk menjaga kebersihan dan kesehatan selama pandemi covid-19.

\section{Ekstraksi Daun Sirih}

Pembuatan ekstrak daun sirih dilakukan metode infusa yang dilanjutkan dengan steam atau kukus. Daun sirih yang sudah dicuci bersih kemudian dipotong-potong. Sebanyak 12 lembar daun sirih dimasukan kedalam wadah ditambah sebanyak $200 \mathrm{ml}$ air, kemudian dikukus atau disteam diatas panci yang sudah diberi air selama 15 menit. Setelah itu wadah diangkat dan didiamkan sampai dingin kemudian disaring. Pembuatan handsanitizer ekstrak daun sirih ditambah dengan bahan-bahan seperti $100 \mathrm{ml}$ air, 1 buah perasan jeruk nipis yang telah disaring. Semua bahan dicampur rata kemudian disaring dan dimasukan kedalam botol.

\section{Ekstraksi jeruk nipis}

Ekstrak etanol buah jeruk nipis memiliki aktivitas antibakteri terhadap beberapa bakteri. Jeruk nipis yang sudah dicuci bersih kemudian dipotong kemudian diperas dan disaring kedalam wadah. Setelah itu perasan air jeruk nipis dicampurkan dengan rebusan air daun sirih.

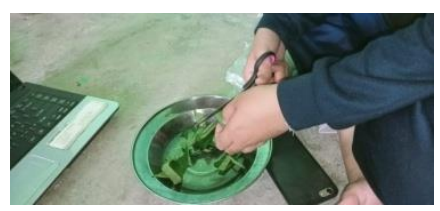

Gambar 1. Potongan Sirih 


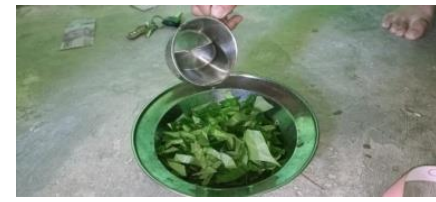

Gambar 2 Tambahkan air 100 $\mathrm{ml}$

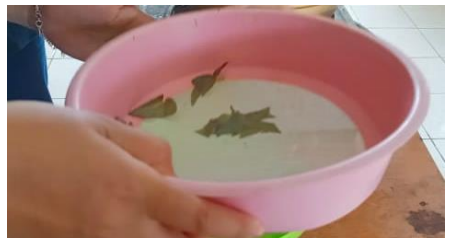

Gambar 5 Saringan rebusan air sirih

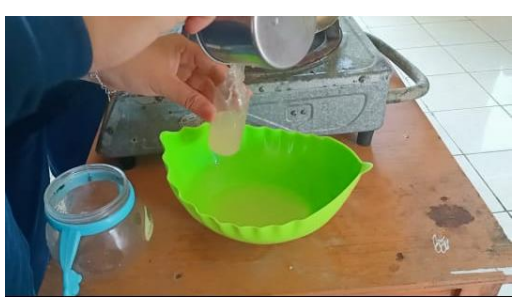

Gambar 8 Campuran dimasuk kedalam botol

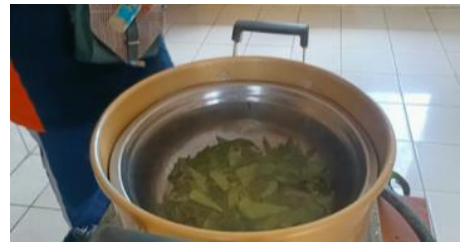

Gambar 3 Kukus/steam daun sirih

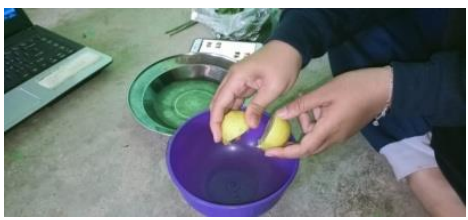

Gambar 6 Perasan jeruk nipis

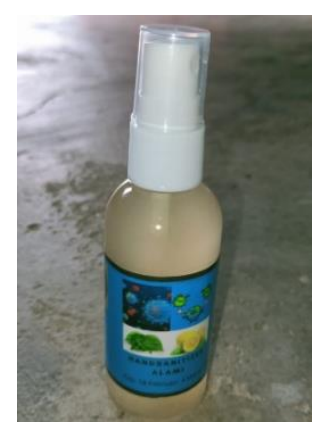

Gambar 9 Handsanitizer

siap dipakai

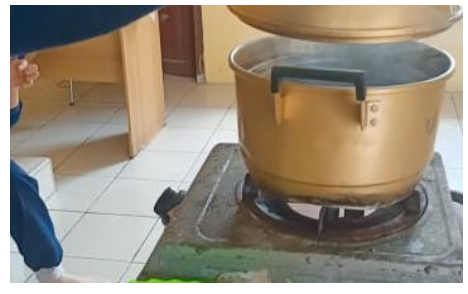

Gambar 4 Diamkan selama

15 menit

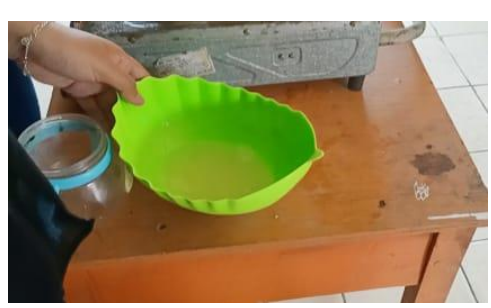

Gambar 7 Campuran air sirih dan jeruk nipis

\section{KESIMPULAN}

Program kegiatan KKN Universitas Muhammadiyah Bangka Belitung "Pelatihan Pembuatan Handsanitizer Alami dengan Ekstrak Daun Sirih dan Jeruk Nipis untuk Mencegah Penyebaran Covid-19 di Desa Cupat Parittiga” berhasil dengan sangat baik berkat bantuan doa, dukungan, dan kerjasam antara semua warga. Masyarakat desa cupat RT 10 kecamatan Paritiga kabupaten Bangka Barat menyambut sangat baik dalam kegiatan membuat inofasi produk handsanitaizer dari ekstrak daun sirih dan jeruk nipis. Dengan adanya pelatihan pembuatan 
handsanitaizer alami yang telah kita sampaikan kepada masyarakat khususnya desa Cupat, dapat memanfaatkan potensi alam yang ada yaitu daun sirih dan jeruk nipis yang dapat dijadikan handsanitaizer alami ditengah pandemi seperti ini. Manfaat lain dari kegiatan ini adalah warga dapat membuat handsanitaizer sendiri dan menghemat biaya pengeluaran. Dengan adanya pelatihan pembuatan handsanitaizer alami dapat membantu pemerintah dalam mencegah penyebaran covid-19 khususnya di desa cupat

\section{UCAPAN TERIMA KASIH}

Banyak pihak yang telah mendukung dan memberikan izin dalam pelaksanaan kegiatan ini sehingga penulis mengucapkan terimakasih kepada kepala Desa, perangkat Desa dan masyarakat Desa Cupat, Kecamatan Parittiga, Kabupaten Bangka Barat dan segenap civitas akademika Universitas Muhammadiyah Bangka Belitung.

\section{DAFTAR PUSTAKA}

Ahmad Muhlisin. (2019). Manfaat Jeruk Nipis dan Kandungannya. Diakses 22 Februari 2019. https://www.honestdocs.id/kandungan-manfaat-jeruk-nipis-bagi-kesehatan-kecantikan.

AR Chaerudin, Bambang Setiadi, \& Ahmad Munawir. (2020). PEMBERDAYAAN EKONOMI MASYARAKAT BERBASIS EKONOMI KREATIF DI DESA CITAMAN KECAMATAN CIOMAS KABUPATEN SERANG BANTEN. Jurnal Abdimas Bina Bangsa, 1(1), 26-37. doi:10.46306/jabb.v1i1.9

Caroline, dkk. 2016. 'Potensi Daun Sirih Hijau (Piper betle L) untuk Terapi Alternatif Acne vulgaris', Jurnal Majority, 5 (1), 140-143.

Prasadi, O., Nurlinda Ayu Triwuri, Dwi Novia Prasetyanti, Eka Dyah Puspita Sari, \& Agus Santoso. (2020). PENERAPAN STANDAR CARA PRODUKSI PANGAN OLAHAN YANG BAIK (CPPOB) DI CILACAP. Jurnal Abdimas Bina Bangsa, 1(2), 215-222. https://doi.org/10.46306/jabb.v1i2.29

Susilo, dkk. (2020). 'Coronavirus Disease 2019:Review Of Curret Literature, 'Jurnal Penyakit dalam Indonesia'. 7(1), 24-47.

Thalib, Abdul. 2020. 'Herbal Potensial sebagai Hand Sanitizer di Indonesia: Literatur Review. Jurnal Pasapua Health', 2(1), 31.

Yuliah, Raden Irna Afriani, \& Ina Khodijah. (2020). PEMBERDAYAAN PEREMPUAN DAN DIVERSIFIKASI OLAHAN IKAN BANDENG DI DESA SAWAH LUHUR. Jurnal Abdimas Bina Bangsa, 1(2), 153-161. doi:10.46306/jabb.v1i2.15 